\title{
Fashions in English or a standard?
}

CHARLES-JAMES N. BAILEY

\section{Abstract}

Because of the inextricably authoritarian sense attached to 'standard language' in Europe, nonauthoritarian and, as has proved to be the case, ultimately indefinable uses of 'standard English' by Anglo-Saxon scholars cause untold confusion among non-Anglo-Saxons. This article discusses anomalies resulting from this confusion, including deleterious effects on the learning of English in Europe and elsewhere. Although the authoritarian attitude can probably never understand the role of fashion and style in English (despite exact parallels with fashions in other kinds of social behavior), this paper claims that it is precisely such an attitude that is necessary. Anecdotes and logical arguments are offered in support of the writer's thesis. The particularly baneful practice of equating some putative and indefinable formal 'standard' English and normal English with, respectively, European standard and diaiect by persons that have specialized in English for years illustrates the cultural gulf that will have to be crossed if progress is ever to be made. The article concludes with a list of some of the injuries to language-learning and scientific truth that eventuate from laying stress on formal language, which inevitably accompanies stress on a 'standard'.

Among the many faux amis that cause difficulty for foreigners learning English - for example, 'learn', 'science', 'liberal' - is the term standard. Whatever it may mean in English, in Europe it not only means a fixed and unitary thing; it also carries heavy connotations of being prescribed by the central government. In what follows, these two sides of the European concept should be kept in focus. For the European, a standard form of a language is an invariant and formal usage that varies no more according to style than according to region. Besides being prescribed by governmental authority as 
something to be learned by every school child, it is commonly an artificial language - that is, not native to anyone - that any educated person is expected to be able to use on call. A standard language requires two authorities: the standardizer and the central enforcer - in other words, an educational authority.

When speakers of English refer to different standards, this is more or less gobbledygook to any European because of the anomalous plural. The European (and Japanese, etc.) simply assume that someone has standardized a single formal style of English which the central government requires to be learned by all school children. Even teachers with decades of experience react with disbelief when informed that no pronunciation, standard or other, has ever been taught (in either an optional or required course) in schools in Britain, America, Canada, Australia, Ireland, or New Zealand. (That students on the B.B.C. English program, The final year, do not speak what foreigners have been led to believe is 'standard English' fazes them not one bit.) It is true (Crowley 1987) that some teachers' colleges have provided speech training, and old-fashioned girls' schools in many parts of North America and in Britain provided elocution lessons; however, these were given in whatever form of speech was fashionable at the time in the place in question. The person starting out with an authoritarian view of language and standardness will, of course, equate all this with his or her own view, failing to understand that fashions - in dress, in music, and in language - can be just as effective an inducer for non-lames ${ }^{2}$ to copy a model as authority is, especially among teenagers. The difference is that one is free to choose which fashion-setter one prefers, at least to a certain degree: one would pay a price in many schools for resisting peer pressure - in language, as well as in dress. The reaction to authority on language matters is evident in the way radio announcers in Britain and Australia have ignored dictums from on high. But fashion in language is so strong that native-speakers who have not studied linguistics and do not understand the mechanisms of language often think that fashion is a standard (in a sense, of course, it is); and native-speakers of English also fall into the error that only one pronunciation of a word, the one that resembles the spelling most, is truly correct, in all styles, even though they would not be caught dead practising what they preach. ${ }^{3}$

Since everything that is not 'standard' is 'dialect' in Europe, normal (that is, informal) styles of English are outside the scope of standardicity. Could anything be more obvious to Europeans than to equate their concepts of formal standard language and dialect with formal and normal English, respectively? So a style that a native-speaker of English might use once in three 
hundred times, and then usually for emphasis or as a put-down, may be held up to the poor school child as being standard English. And the resemblance of this style, full of archaisms in the form in which it is taught (were is supposed to sound like wear and ware), is presented to the child as good current English. The fact is that it often deviates from good English in many ways with re-present for represent ${ }^{4}$ into for in, examples of pied-piping like 'He wondered about on what her thesis was' (which violates three rules; Bailey 1986d), and so on. The whole stylistic scale (in cultivated or uncultivated types, with regional differences especially where pronunciation is concerned) from formal to normal clashes with the very concept of a standard. This alone would advise against using the term, even if the reality of Anglo-Saxon views on authority, especially in connection with language, did not overwhelmingly militate against the usage. That formal styles are not acceptable in situations requiring normal usage is not an idea that the believers in 'standard English' (many influenced by formal or old literature) who I have met seem to have devoted much attention to. A great irony of the whole business is that these true believers can neither point to the authority that has allegedly standardized English (except the author of the dictionary discussed below) nor tell you how they know that such-and-such an item (taken, say, from a prestige magazine or book) does or does not belong to standard English. The very fact that English people or Americans discuss just what is standard English - in general and in particular - is recreant to the possibility of there being any. For where a standard exists, it can be pointed to, and everyone knows just what it is.

It is depressing to find people who have taught English for many years not knowing how to use a dictionary. ${ }^{5}$ If a pronunciation is listed, it must be acceptable to all on all occasions, they maintain, oblivious of the unsuitability for the young of many uses acceptable among the elderly and of the unacceptability of formal usages in informal situations. Of course, many academics in literate cultures exhibit an almost pathetic reliance on the printed word. With its emphasis on written English and the peculiar way literature is now taught - concentrating on 'Kafka's dick' instead of style - such studies offer the teacher more obstacles than help. And the lexicographers are delinquent when they ignore stylistic labels, though the wide-spread inability to use a dictionary goes further: the naive user of the dictionary, having found $[t]$ at the end of 'act' or 'soft' and the pronunciations given for -s, -ness, and -ly, simply adds them together without deleting the $/ / t / /$ in normal styles, thus producing hardly pronounceable oddities like ['æects] ${ }^{6}$ and ['softnIs] - alongside others like the noun clothes with 'th', which school children are drilled 
to produce here, though (unsurprisingly) they virtually never succeed, since only creatures with forked tongues can place the tongue tip in two places at once (cf. Bailey 1985a: 96-97, 130).

Freshmen come to the university with the strangest ideas about what is acceptable or fashionable (especially among people their age) in English and have never heard of the daughter languages of English - not even of the ones that have become national languages of more countries than the Englishspeaking nations. But then, they are just reflecting what their teachers think and teach. I often present students with news clippings from Singapore, London, the U.S., and Sydney, asking them which is British, or American, or whatever. It is a salutary experience for them: how such a degree of unity could develop without a standardizer must mystify them considerably.?

But the most lamentable failing really involves ignorance of Anglo-Saxon culture. That 'experts' could actually believe that Anglo-Saxon central governments could standardize the language and enforce their product on local school boards - any more than they could send teachers a list of how many points to deduct for each error, as is done in Germany - betrays something that goes far beyond the language problem (see Bailey 1981, Harris 1983). On the other hand, Anglo-Saxons seem quite unaware of the extent that European and Japanese governments are allowed to prescribe standards in every walk of life - not simply those affecting weights and measures and dangerous products, as in Anglo-Saxon lands. Where producers' or consumers' associations in Anglo-Saxon nations create bar codes, paper sizes, etc., as well as ways to 'recognize' the quality of one's formal education, this is nearly all done by the governments of European countries. Even the titles that store clerks and other workers use in addressing one another can be defined by law in Europe.

The irony is that the upholders of standard English cannot (that is politer than simply saying that they know better but 'do not') punctuate English in an acceptable English manner. ${ }^{8}$ What is worse, when students who are convinced of the standardness of the English they have learned travel to England or some other English-speaking country, they dismiss the real English they hear as nonstandard and return home with the same holes in their knowledge of English as when they left: pronunciations never heard among nativespeakers like aktchun for akshun ('action') and 'Why?' in places where it is stilted (instead of 'How come?' or 'What for?') for Warum? or Comment?, as well as complete unawareness of the double pluperfect or where it is used and an off-putting overuse of foregrounded prepositions with interrogative and relative pronouns - and that irritating proliferation of 'whom' (a word that native-speakers have many strategies for avoiding; Bailey 1986d: 163) 
that lends such an alien tone to their 'English'. It does not help, of course, that native-speakers frequently use formal English with foreigners. At all events, it is no secret that students from countries with the strongest presuppositions about, and emphasis on, standard language profit least from visits to an English-speaking country and learn English least satisfactorily. As for those that do not visit such countries, one would think, given the emphasis on the history of English which exists, that students would have a better understanding of the force of the citations in the Appendix to this article. But, again, unwarranted cultural transfers block this understanding.

The argument that those who use the term 'standard English' are doing their students much more harm than good can be taken beyond logical demonstration to arguments from absurdity. Two examples will have to suffice.

The first involves the uncanny inventiveness of foreign authorities on English, who at times exhibit an arcane ability to tell you exactly what items belong or do not belong to 'standard English'. When a local examination authority insisted to me that such-and-such a word was not part of 'British standard English' and I replied, 'Who cares? You still have to be able to read The Economist if you're to claim expertise in English', I have no doubt that my reply made little sense to him. The size of the cultural misunderstanding can be gauged by the fact that I have never met a native-speaker of English teaching in Europe for a few months or more that did not admit that he/she had been corrected by a European 'expert' at some time (never mind that the corrector could not have gained admission to the universities that the person being corrected graduated, even with honors, from); the list of such people includes persons sent to Europe by the British Council to train teachers, as well as testing directors from Britain. It is evident that the gulf between Anglo-Saxon and other views is greater than commonly supposed. The deplorable aspect of the matter is that such courses on Anglo-Saxon culture as I have met with in Europe have been inadequate, whether concentrating on the past (how British labor unions got started) or in other ways. The products of such teaching could not explain why so many American and British movies (and so few European ones) focus on the defeat of the bully by the bullied.

Another example of the consequences of belief in a standardized English concerns such a transmogrification of the language in an alien mould as to actually reverse the intention of the man's terminology. Daniel Jones, a British phonetician of whom few English experts in the Anglo-Saxon countries seem to have heard, but who appears to be widely believed in Europe to have 
standardized English pronunciation, coined the term 'Received Pronunciation' (RP) with the express purpose of distinguishing what he described (not prescribed) from 'standard pronunciation', a concept he explicitly rejected (see Appendix). (He claimed to be describing the upper three or four percent of the speech of English people, not a standard for all school students.) Ignoring what the man said, unwary teachers have referred to his (now obsolete) RP pronunciations as 'standard pronunciation'. This stands the man's terminology on its head and has him saying the opposite of what he really said. ${ }^{9}$ All of that is aside from the repugnance which such weighted terms from the class system of that era have for today. But this is of a piece with the other static traits of the language teacher who appears to assume that neither the social system nor educational opportunities in Britain have changed in any way that would affect the English spoken there since the Second World War.

And yet, where have these changed more in the last fifty years? I have had several Germans tell me that, as boys, they had been required by their school teachers to recite the Queen's coronation speech exactly the way she delivered it forty years ago! Greater flights into cloudcuckooland - with such a total misunderstanding of English - than this there are not. Are such teachers unaware of the way older speakers of English, unlike those of many other languages, emulate the speech fashions of the young? I would find it unrealistic to suppose that even a German would wish his or her little boy to speak the way a German lady did in the early fifties.

The basis of language confusions - for example, the false-friend status of standard referred to above - is due mainly to cultural confusion. On the subject of language (and much else), there exist an authoritarian outlook and a libertarian (even anti-authoritarian) outlook. When many Europeans speak of standard English, they, naturally enough, cast it in their own cultural mould; few seem able to bridge the cultural gap between the Anglo-Saxon outlook and their own: that acceptability might be a matter of fashion, that a speaker or writer might feel a great deal of freedom to choose which pacesetter of fashion (a disk-jockey, popular entertainer, sports hero, or even, sometimes, a writer) he/she would emulate, and that a speaker or writer of English might even have the freedom to side-step fashions altogether and become a lame. All this must seem like another world to teachers of English, including those that have lived and even studied in Anglo-Saxon countries (see also Bailey 1985b, 1986b).

But let us proceed one step further to see how the mechanisms of fashion function in social matters - most efficaciously in language. The basic prin- 
ciple (Bailey 1986a,b) is that all those who imitate another have less prestige in that respect than the one(s) imitated; expressed otherwise, a usage that cedes to another has less prestige than the one that usurps its place. To understand this in any really meaningful way requires giving up the static outlook that most teachers (and linguists) are immersed in. Static numbers are irrelevant: what 'most' people do is not relevant for prestige; after all, the imitators of social fashions often outnumber the few that set the pace. What is at issue is rather a usage that is growing and encroaching on another; this is what should concern a proper investigation concerning which variant is more fashionable or has more prestige. When the 'vectorial' analysis is employed, a good deal that is taught in European schools about the prestige of various kinds of English in the world or about the statuses of the main varieties of English in the U.S.A. is seen to be erroneous.

But then we run up against the inertia of human laziness - in great part due to teachers' tenure status. Whereas it is easy to check a single, static standard to find out what is 'good', it takes vastly more effort than your average teacher is willing or able to expend (or has to expend to retain her or his job) to keep oneself up-to-date on the latest fashions of English; for example, the recently fashionable pronunciation on the B.B.C. of so-called 'short- $a$ ' as $\left[\mathfrak{x}^{\mathrm{I}}\right.$ ] preceding $/ / \mathrm{g} / /$ and $/ \mathrm{g} /$ in the same syllable, as in 'Maggie', 'bang', 'bank', and 'sanctions', as heard on recent newscasts. The problem goes yet deeper, because even a teacher that might feel some motivation to keep up-todate really does not know how to do so. Teachers have not been trained to listen to real English and so fall into the naivetés of ignoring Labov's 'Observer's Paradox' $(1972: 61 \mathrm{f}, 69,209)^{10}$ when seeking to obtain data.

One can name a number of drawbacks that directly follow from the view that only formal - which often means obsolescent - usages are standard.

1. I have found that the extent to which older speakers of English imitate the uses of younger speakers is not infrequently incomprehensible to Europeans, the Japanese, and others. I once pointed out to my students, as we were examining the front page of an edition of The Guardian, that the journalist treated 'the B.B.C.' as a singular whereas the retired president of that organization was quoted as treating it as a plural. When I asked the students which was correct, they had the good sense to avoid that pitfall and replied that both were correct (see Bailey 1987). ${ }^{11}$ After I agreed and persisted with the further question, 'Which usage should you teach the children when you become a school teacher?', they were at a loss until I pointed out the age differences that one could infer about the journalist and the retired president of the B.B.C. At this point, those who had an opinion chose the usage of the 
latter. Their concept of linguistic prestige was based on a non-English concept; what made sense to them is ridiculous to the native-speaker.

2. The emphasis on formal usages propagates not only the 'Monostylistic Curse' but also its causes, ignoring the 'Layperson's Trap' and the 'Principle of Peeling the Onion' (Bailey 1986a,b). It is easy to show that the more informal and unmonitored one's styles become, the more rules - syntactic as well as phonetological (for example, assimilation rules) - one adds in a progressive order, in addition to reordering these rules. It follows, too, that the full set of rules is found in the most unmonitored, the most informal, usages. Progressively more formal styles make use of progressively smaller subsets of this full set. From which it is clear that those who can use the most informal English have the more formal styles at their command, while those who know formal English do not have increasingly normal styles at their disposal. The result is the 'Monostylistic Curse'. Underlying these misconceptions is the 'Layperson's Trap' already alluded to: the failure to realize that rules exist to alter underlying syntactic and phonetological units or structures. An example has been given earlier in the deletion of $/ / \mathrm{t} / /$ in 'acts,' 'softness', and 'softly'. Since stylistic diversity depends on differing rules, ignoring them can only lead to monostylism - and the worst kind of it at that.

3. Real errors arise when one ignores styles. I will leave aside the sometimes comical mixing of syntactic and phonetological styles in the schoolbooks and restrict myself to their rule that 'not' directly follows the auxiliary verb. ${ }^{12}$ This is of course wrong and rules out the distinction between the unmarked readings of 'Can't they go?' and 'Can they not go?'. The heart of the error is the assumption that $-n$ ' $t$ is a (deviant) form of 'not' - a stylistic error.

The 'Monostylistic Curse', that stylistic insensitivity that stems partly from the emphasis on formal and older literature and partly from the misguided emphasis on 'theory'13 instead of style ${ }^{14}$ in that art - which is treated by a large number of its practitioners as though it were a 'scientific' discipline proceeds from the, for English, fallacious assumption that formal is always better. That native-speakers seldom use formal styles, and by no means always politely, should carry weight with the foreign teacher of English.

The head of this dragon is the notion of 'standard English'. The question that must be faced by teachers is 'Are they not harming their students when they employ this term?'. Do they even know what they are really talking about? How could the term make sense under the political traditions of the Anglo-Saxon world or in the case of a language with native-speakers on all continents of the world, leaving aside the fact that there are more non-native- 
speakers in the world than in any Anglo-Saxon country except probably the United States?

\section{Technische Universität Berlin}

\section{Appendix}

If an academy should be established ... which I, who can never wish to see dependance multiplied, hope the spirit of English liberty will hinder or destroy. ...

[Swift] proposes to secure [these things] by instituting an academy; the decrees of which every man would have been willing, and many would have been proud to disobey. (Samuel Johnson, in the Preface to his English Dictionary, 1775)

... not that I would be thought, in the most distant manner, to deny that custom is the sovereign arbiter of language; far from it. I acknowledge its authority, and know there is no appeal from it. . . . if once custom speaks out, however absurdly, I sincerely acquiesce in its sentence. (John Walker, A Critical Pronouncing Dictionary and Expositor of the English Language, London 1820: viii)

Language is mobile and liable to change, and . . . a very large number of words have two or more pronunciations current .... and giving life and variety to language ... it is a free country, and a man may call a vase a vawse, a vahse, a vaze, or a vase, as he pleases. And why should he not? We do not all think alike, walk alike, dress alike, write alike, or dine alike; why should not we use our liberty in speech also, so long as the purpose of speech, to be intelligible, and its grace, are not interfered with? (James A. H. Murray on the Oxford English Dictionary, which he founded and edited from 1878)

I would add here that I do not regard RP as intrinsically 'better' or more 'beautiful' than any other form of pronunciation. [He has observed in an earlier footnote that his own usages do not always agree with those he gives the first place to in his listings.] ... I wish also to state that I have no intention of becoming either a reformer of pronunciation or a judge who decides what pronunciations are 'good' and what are 'bad'. My aim is to observe and record accurately, and I do not believe in the feasibility of imposing one particular form of pronunciation on the English-speaking world. I take the view that people should be allowed to speak as they like . . . it must be left to [any who think otherwise] to undertake the invidious task of deciding what is to be approved and what is to be condemned. (Daniel Jones, author of the English Pronunciation Dictionary, from 1917) 
... America is leading the way now, not Britain. (Robert Burchfield, retired ed. of supplementary volumes to the Oxford English Dictionary, referring to changes in English)

After noting how undergraduates of modest backgrounds tended in the 1920 's to emulate the speech manners of the upper-class public schools in Britain, he goes on to observe that 'nowadays it is the other way round. The richer and more upper-class the undergraduates, the more prone they are ... to cultivate a nondescript accent which might belong to anyone anywhere'. $\mathrm{He}$ relates this to the world-wide social revolution 'for which America has provided the musical accompaniment - rock - and the uniform - jeans'. (Malcolm Muggeridge, Time, Dec. 3, 1979: 33)

American English is definitely the model, not English - this is what we see looking through French advertising. (Micheline Faure, organizing secretary of AGULF, formed to resist the invasion of English in France)

A foreigner can pick up an Americanized vocabulary 'if you want to show you're with it and talking like Americans, the most fashionable people on earth'. (Randolph Quirk, author of major grammars in England, founder of the grammar group in London)

\section{Notes}

1. One sees in countries like Germany or Israel signs pointing to the cash(ier's) desk labeled with the meaningless 'cash' (as though Kasse or caisse). One hears people say, precisely in order to extenuate their not having learned English, that they 'learned it only a few years at school'. (See also n. 13, for a comparable error on the part of native-speakers in literature.) A good test that teachers can give themselves is to name the kinds of engineers that can and cannot be called 'scientists'; my research shows that the answer is the same for Britain, the U.S., Canada, Australia, etcetera. A severe problem arises with equating 'must' with 'müssen', something that mars nearly all the textbooks I have examined: 'must' is stronger than 'hafta' and 've gotta' (except in epistemic and comparable uses) because, unlike them, it presupposes the power to command. (That is also why 'can' is politer than 'may', at least in speaking to those one is in a position to command and give permission to.)

2. A lame is a person who stands 'outside', not participating in the on-going creativity of the English language.

3. Educated speakers find spelling pronunciations like ' $w$ ' in 'sword' (formerly, also 'i' in parliament) quite amusing and bemeaning. Clearly, there is no consistency here.

4. I have often wondered how usages like 're-present' for 'represent' and dozens of others one could cite which have never been heard from the mouth of a nativespeaker (except in discussions like this) or, in the case of 'represent' and 'recollect', never found in a dictionary, could have been adopted; it is easy to see why, once 
adopted, they are so tenacious. Students often exhibit amazement to learn that we put money in our pockets and into stocks and bonds; what they have been taught is quite different. It is worth pointing out that the teaching of English suffers more in the wealthier countries than in the poorer ones; the reason for this is that the poorer ones have to rely more on materials produced by nativespeakers (which look like real English), they have fewer funds for dubbing English films, etcetera.

5. Many teachers seem unaware that, despite a few notable exceptions, most dictionary-makers, so far from being experts and standardizers, are less well trained in current linguistic concepts and the nature of English than the average younger linguist.

6. For the fac(t)s, see Bailey (1985a: 65). In slow pronunciation, of course, the ' $c$ ' in 'acts' is longer than that in 'axe', but they are homophonous in allegro tempo.

7. There are differing reasons for the asymptotic approach to unity in syntax and diction, on the one hand, and pronunciation on the other, in English. There is little borrowing of the pronunciations of one country by speakers of English in another. Pronunciation has become the factor that tells the listener where the speaker is from; since people are proud of their origin, they do not give up their identity in this respect even as they gladly assist the convergence of English in the syntactic component. Diction spreads around the world more easily than any other aspect of English, America being the pace-setter for this.

8. The school books have improved their use of more up-to-date English in the past decade, though one often sees products that can scarcely have been vetted by a native-speaker with talent for this kind of work; but the format and punctuation are still generally unrecognizable as English. The list of points deducted for each error in English which the responsible cabinet official in Berlin gives to school teachers is widely and reliably reported to have no points off for punctuation mistakes. The official in question is obviously unaware of the different rationales of English and German punctuation - sense and structure, respectively (Karl Maroldt, p.c.) - or of the fact that, since English punctuation fills many of the roles filled by inflection in German, it is no more to be treated as a minor point than inflection is in German.

9. Despite Jones's express words, Crowley (1987) finds that he and others actually had standardizing intentions. But the fact that Jones disguised his intentions in the manner he did (Wyld admitted he was undemocratic) shows the degree to which authoritarian views of language are suspect in the English-speaking world. Crowley's article is especially interesting in illuminating the contradictions one runs into in trying to define as a standard what cannot be a standard.

10. The 'Observer's Paradox' has to do with the effects of the observer on the observed. Since people can refer to their language only when they monitor it (see the 'Principle of Peeling the Onion' below), without prevarication they will deny that they say in their normal usage what they normally do, and they will affirm that they say what they seldom or never say in those styles.

11. On the other hand, one student maintained that, since he had been taught not to use 'be going to' or 'will' after 'if' (the rule actually applies to all subordinate clauses, other than indirect questions, embedded under high futuritives), The Guardian's use of 'If you're going to get people to co-operate' was therefore 'incorrect' (for the correct answer, see Bailey, forthcoming).

12. One local textbook writes -'s for 'is' after personal pronouns but not elsewhere. It is hard to avoid the prejudice that native-speakers can do a better job of inventing 
English than others, that others should leave that job to native-speakers. That such stylistic incongruities as result from practices like the one just cited could be tolerated in a current textbook illustrates a profound insensitivity toward the vast differences in the roles that style plays in good English and good German.

13. 'Theorie' (as well as 'Technologie', etcetera) in German is used much more widely than its English congener; for example, the two driver's exams are praktisch and theoretisch, the latter being a test of one's memory of the driving regulations. Literary Theorie has been mistranslated (by those literature experts who should know better) as 'theory', with ludicrous results in English.

14. The use of 'Mrs.' for 'M(is)s' in English reflects the German's preference for 'Frau' over 'Fräulein'. The use of 'Mr.' to one's fellow workers displays a good knowledge of German customs but bad English; 'Herr' would be better even in English. One thing sadly lacking among European students of English is a facility for making polite (and, especially, delicate) requests.

15. For other problems, see Bailey (1985b, and unpublished).

\section{References}

Bailey, Charles-James N.

1981 Standard nonsense. Scottish Literary Journal (Supplement) 14, 63-65.

1985a English Phonetic Transcription. Dallas: S.I.L. and University of Texas at Arlington Press.

1985b Untapped principles of language-teaching. Journal of Literary Semantics 14, 56-70.

1986a Even dialectologists get the blues: Inadequate phonetic transcription of English. Papiere zur Linguistik 35, 1-38.

1986b Fundamental problems in teaching cross-cultural communication. In J. H. Koo and R. N. St. Clair (eds.), Cross-cultural Communication: East and West. Seoul: Samji.

1986c Remarks on standardization, English, and possibilities in developed and developing countries. In G. Nickel and J. C. Stalker (eds.), Problems of Standardization and Linguistic Variation in Present-day English. Heidelberg: Julius Groos, 79-83.

1986d Where English cannot put the preposition before a relative or interrogative pronoun. In G. Leitner (ed.), The English Reference Grammar: Language and Linguistics, Writers and Readers. Tübingen: Max Niemeyer, 156-177.

1987 Marginalia on singular and plural in English. Arbeiten aus Anglistik und Amerikanistik 12, 3-11.

Forthcoming Classifying the English conditionals. American Speech.

Unpublished Content-sequencing and other aspects of teaching English to foreigners. Crowley, Tony

1987 Description or prescription? An analysis of the term 'standard English' in the work of two twentieth-century linguists. Language and Communication 7, 199-220.

Harris, Roy

1983 Beware of standards. The Times Educational Supplement, February 25.

Labov, William

1972 Sociolinguistic Patterns. Philadelphia: University of Pennsylvania Press. 